\title{
Integrated Renewable Energy Systems in Fruit and Vegetable Processing Industries: A Systematic Review
}

\author{
Sofia Lewis Lopes, Elizabeth Duarte, and Rita Fragoso
}

\section{ABSTRACT}

The exponential population growth will put great pressure on natural resources, agriculture, energy systems and waste production. New business models and innovative technological approaches are necessary to tackle these challenges and achieve the energy transition targets set by the European Commission. Renewable energy technologies and processes such as solar photovoltaic, solar thermal and anaerobic codigestion have become a subject of interest and research as a solution that could be fully implemented in industries and solve several environmental and economic problems. This paper discusses the possibility of integrating and complement these technologies to maximize renewable energy production and circularity.

The review was performed with a funnel approach aiming to analyze broad to specific subjects. Beginning with a literature review on the various definitions of circular economy, bioeconomy, and circular bioeconomy, ultimately proposing a single definition according to an industrial and academic scope combination, followed by a systematization and assessment of data and literature regarding energy systems present state and projections. The next phase was to assess data and literature of the fruit and vegetable processing industry from an energy consumption and biowaste production perspective to consequently discussing technologies that could help manage problems identified throughout this review. This paper culminates in propounding an Integrated Renewable Energy System conceptual model that promotes energy and waste circularity, envisioning how industries could be designed or redesigned in the future, coupled with a circular bioeconomy business model.

Keywords: Anaerobic Co-digestion, Biowaste, Circular Bioeconomy, Fruit and Vegetable Processing Industry, Hybrid Photovoltaic-Thermal Solar Systems, Integrated Renewable Energy System.
Published Online: August 21, 2021

ISSN: $2736-5506$

DOI : 10.24018/ejenergy.2021.1.3.13

S. L. Lopes*

LEAF - Linking Landscape, Environment, Agriculture and Food, Instituto Superior de Agronomia, Universidade de Lisboa, Lisboa, Portugal.

(e-mail: sofialewisl@outlook.com)

E. Duarte

LEAF - Linking Landscape, Environment, Agriculture and Food, Instituto Superior de Agronomia, Universidade de Lisboa, Lisboa, Portugal.

(e-mail: eduarte@isa.ulisboa.pt)

R. Fragoso

LEAF - Linking Landscape, Environment, Agriculture and Food, Instituto Superior de Agronomia, Universidade de Lisboa, Lisboa, Portugal.

(e-mail: ritafragoso@isa.ulisboa.pt)

*Corresponding Author

\section{INTRODUCTION}

According to the World Bank's projection, in 2050 the world population will be approximately 9 billion people compared to our current population of 7.5 billion people [1]. Therefore, food demand will increase by $50 \%$ between 2012 and 2050 [2], causing uncertainty of how the current food system will be able to provide and sustain the world population by 2050 .

Additionally, producing more food using a "business as usual" approach could lead to depletion of natural resources and contribute to climate change. It is necessary to use a different strategy in order to achieve a sustainable food and agriculture system [3].

Another challenge visibly linked to population growth will be the increase of waste generation, global annual waste generation is expected to rise to 3.4 billion tonnes over the next 30 years, up from 2.01 billion tonnes in 2016. Solid waste related emissions are expected to increase to 2.6 billion tonnes of $\mathrm{CO}_{2}$-equivalent per year by 2050 if no improvements are made in the sector [4].

Furthermore, energy consumption has a large contribution to greenhouse gas (GHG) emissions and therefore several countries or organizations have already made efforts to accelerate the process of energy transition by structuring strategies to increase renewable energy sources (RES) and energy efficiency improvement.

For example, the Nordic countries (Denmark, Finland, Iceland, Norway and Sweden) planned to be fossil free by 2050. The International Energy Agency (IEA) carried out the Clean Energy Transitions Programme to facilitate global energy transition. China also has set short-term strategies at a regional level. Over the last decade, the European Union (EU) has pursued a proactive climate policy and has integrated a significant percentage of RES into the energy system [5]-[9].

The report "Fostering Effective Energy Transition 2020 Edition" by the World Economic Forum 2020 analyses the 
progress of energy transition by country, creating an Energy Transition Index (ETI). This index measures each country's readiness for the energy transition, allowing achieve an overview and insight of how countries are delivering their strategies and tracking progress on energy transition [10].

Focusing on the EU geographical area, due to the urgency of addressing the challenges described above, most recently the European Commission (EC) released The European Green Deal. Citing the Commission, the new strategy aims to "transform the EU into a fair and prosperous society, with a modern, resource-efficient and competitive economy where there are no net emissions of greenhouse gases in 2050 and where economic growth is decoupled from resource use". In this deal, there are several areas of intervention namely energy, building efficiency, smart mobility, industry, food systems, biodiversity, and others.

The production and use of energy across economic sectors, is responsible for more than $75 \%$ of the EU's GHG emissions. Therefore, decarbonizing the energy system is essential to reach the climate goals in 2030 and 2050, which can be achieved by increasing the share of RES but at the same time energy supplying must be secure and affordable for consumers.

The industry sector accounts for $20 \%$ of the EU's GHG emissions, becoming the leading player in this transition, the EC has adopted an EU industrial strategy, which together with the Circular Economy Action Plan, offers this sector new sustainable opportunities including modernizing the economy. This circular approach will guarantee a cleaner and more competitive industry by reducing environmental impacts, decreasing competition for limited resources, and reducing production costs [11], [12].

Facing the urgent challenges discussed above, there is a need to develop new business and economic models that in their essence are resource and energy efficient, promoting waste valorization and renewable energy (RE) integration.

New models are emerging such as Circular Economy (CE), Bioeconomy (BE) and more recently Circular Bioeconomy (CBE). These models are being widely discussed and promoted by business advocacy bodies and government entities such as the Ellen McArthur Foundation and the EC [13]-[15].

In 2012 the EC adopted the strategy "Innovating for Sustainable Growth: A Bioeconomy for Europe", that aims to "pave the way to a more innovative, resource efficient and competitive society that reconciles food security with the sustainable use of renewable resources for industrial purposes, while ensuring environmental protection" [16].

The most recent model is CBE and is characterized by the overlap between $\mathrm{CE}$ and $\mathrm{BE}$. This concept was emphasized in the revision of the EC's Bioeconomy Strategy [17]. Biomass waste is recognized as promising feedstock in setting a BE, where food waste (FW) can be considered as a potential source of bio-based products and bioenergy [18].

Therefore, FW valorization has gained interest since many bio-based products can be derived from them, besides bioenergy and biofuels [19]. Within the EU-28 industrial FW quantities are significant, ranging between $19 \%$ and $39 \%$ of the total FW in the EU-28 food supply chains, becoming an interesting source in terms of its characteristics and bioavailability [20].
Circularity opportunities, that can help to speed the EU energy transition, have already been identified to apply industrial symbiosis in valorizing FW from the processing industry. Additionally, FW valorization has the potential to provide economic, social, and environmental benefits [21].

Regarding the increase of RE share in energy systems, this could be achieved by promoting the integration of different renewable energy technologies (RET). Besides bioenergy, we chose to focus on solar energy (photovoltaic (PV) and solar thermal (ST). The two solar energy technologies were chosen due to their rapid growth perspective and the high increase in levels of channeled investment, being one of the most promising markets in the field of RE around the world [22], [23].

To discuss and develop the topics introduced above, this article firstly presents the definition of the concepts associated with the new economic models. Then a literature review of the total energy supply (TES) regarding nonrenewable energy sources (NRES) and RES is carried out. Afterwards, the most up to date data and projections for the next decades regarding energy is systematized. Particular focus is given to the Fruit and Vegetable processing industry (FVPI) due to its large production of biowaste and its potential to implement new business models such as CBE. Finally, a conceptual model integrating different RET to promote circularity and increase RE consumption in FVPI is proposed.

\section{METHODS}

In order to gather the relevant scientific and technical literature for this review, three types of information sources were accessed: scientific articles, reports and databases.

For scientific articles, a planned search was performed through two online platforms Science Direct (SD) and Web of Science (WoS). Using both platforms search engines directly, search settings were selected to narrow down to only relevant results.

The following search filters were set:

- 3-5 specific keywords;

- The search period from 2015-2020;

- Both research and review articles were considered.

The following exclusion factors were also set:

- All duplicate documents were excluded;

- All titles were read and articles that had no relation to the research topic were excluded;

- All abstracts and keywords were read and articles that had no relation to the theme were excluded.

The selected research and review articles were all available in English.

Regarding reports and databases, the official entities named below were chosen as sources of information:

- World Bank (WB);

- International Energy Agency (IEA);

- Food and Agriculture Organization of the United Nations (FAO);

- Organisation for Economic Co-operation and Development (OECD);

- European Commission (EC);

- International Food Policy Research Institute 


\section{(IFPRI).}

Focusing on data, datasets were downloaded through databases available on the official entities website. Regarding the selection of the period, it was set from 2010 up to the most recent and complete available data. Regarding the geographic selection, two categories were selected:

- World - Includes OECD Total; Africa; non-OECD Asia (excluding China); China (P.R. of China and Hong Kong, China); Non-OECD Americas; Middle East; Non-OECD Europe and Eurasia.

- EU-28 - Austria, Belgium; Bulgaria; Croatia; Cyprus; the Czech Republic; Denmark; Estonia; Finland; France; Germany; Greece; Hungary; Ireland; Italy; Latvia; Lithuania; Luxembourg; Malta; the Netherlands; Poland; Portugal; Romania; the Slovak Republic; Slovenia; Spain; Sweden and the United Kingdom.

An up-down approach was adopted, i.e., start by analyzing a general scope and narrowing down to a more specific context and geographical area.

Utilizing Microsoft Excel, specific and relevant data was selected, systemized, and summarized in order to be translated into clear and robust charts for a direct and friendly visualization.

\section{NeW ECONOMIC MODELS - Definition OF CIRCUlaR ECONOMY, BIOECONOMY AND CIRCULAR BIOECONOMY}

\section{A. Circular Economy (CE)}

This concept, although currently extremely popular, dates back to the 1960s, when the economist Kenneth Boulding wrote the first notions of CE in the essay "The economics of the coming Spaceship Earth", which was a pioneering contribution for the concept. Boulding defends a vision of the economic system opposite to the model that he classifies as the "cowboy economy", an exploitative, individualist economy constantly consuming resources that are finite.

Another major contributor and promoter of CE is Walter Stahel, who is known for the pioneer term "cradle to cradle" which is one of the fundamentals for CE. He sketched the concept in 1976 in his research report to the European Commission "The Potential for Substituting Manpower for Energy" [27], [28].

Thus, the CE has a long history, but the concept only became popular in the 1990s with China as a response to their economic growth and natural resources limitation, since it is the largest producer of manufactured goods. Nowadays, the concept of CE has been adopted across the world and been promoted by several organizations.

The concept of CE is now a mainstream concept widely discussed to tackle environmental challenges and promote sustainable development.

However, there is not a consensus of its definition from business, scientific and research approach. Korhonen et al. [13], [29] identify, discuss, and develop the various definitions available in emerging literature. The authors systemized several definitions in a business and academic approach. In the business approach, definitions generally reference and adopt the Ellen MacArthur Foundation definition [30]-[34] whereas the academic approach is based on other researchers [35]-[40].

The business approach definitions focus more on the economic and business logic embedded in the CE concept whereas academic approach is based on relevant research background or an adopted definition from researchers.

Korhonen et al. [13] suggest that a solid definition for CE could tackle severe limitations and challenges in the practical application, consequently the authors developed the concept based on current knowledge that is in line with academic, policy, industry, or economic areas.

Considering Korhonen et al. [29] definition, and in accordance with industrial and academic context, in this review the following definition of $\mathrm{CE}$ is proposed: " $\mathrm{CE}$ aims to higher resource and energy efficiency, minimizing biowaste production and incentivizing the cyclical material flows and cascading use of bio-waste, contributing for three dimensions (economic, social and environmental) of sustainable development."

\section{B. Bioeconomy (BE)}

The term "bioeconomics" can be traced back to Zeman and Georgescu-Roegen in the 1960s and 1970's respectively, the term meant "a new economic order" with the purpose to recognize the biological base of any economic activities.

The concept of bioeconomy became more popular in the 2000s when decision-makers in the EU brought it up to tackle food security, managing natural resources sustainably, reducing dependence on NRES, mitigating and adapting to climate change, creating jobs, and maintaining European competitiveness [16]. The EC defines the bioeconomy as "encompassing the production of renewable biological resources and the conservation of these resources and waste streams into value added products, such as food, feed, biobased products and bioenergy" [16].

There are two approaches in the many definitions proposed [26], [41]-[46], the "biotech-oriented bioeconomy" and the "biomass-oriented bioeconomy".

Based on the several definitions from authors mentioned above and this article being driven by the environmental and energy areas, a biomass-oriented BE is more appropriate, and the following definition is adopted: "Bioeconomy focus on the use of renewable biological resources for the production of a biobased product, converting biowaste into value added production such as food, feed and bioenergy, contributing from both social and economic areas."

\section{Circular Bioeconomy (CBE)}

The concepts of BE and CE have similar targets, such as low carbon economy and reducing the use of fossil fuels, although they have different definitions, they are complementary approaches.

The two concepts are not complete without each other therefore the circular bioeconomy is defined as the intersection or cross-section of BE and CE. It is a very recent concept and it's present in several European organization's agenda, there are different definitions [47]-[50].

Fig. 1 represents the intersection of $\mathrm{CE}$ and $\mathrm{BE}$ fundamentals which originate the concept definition of $\mathrm{CBE}$. 


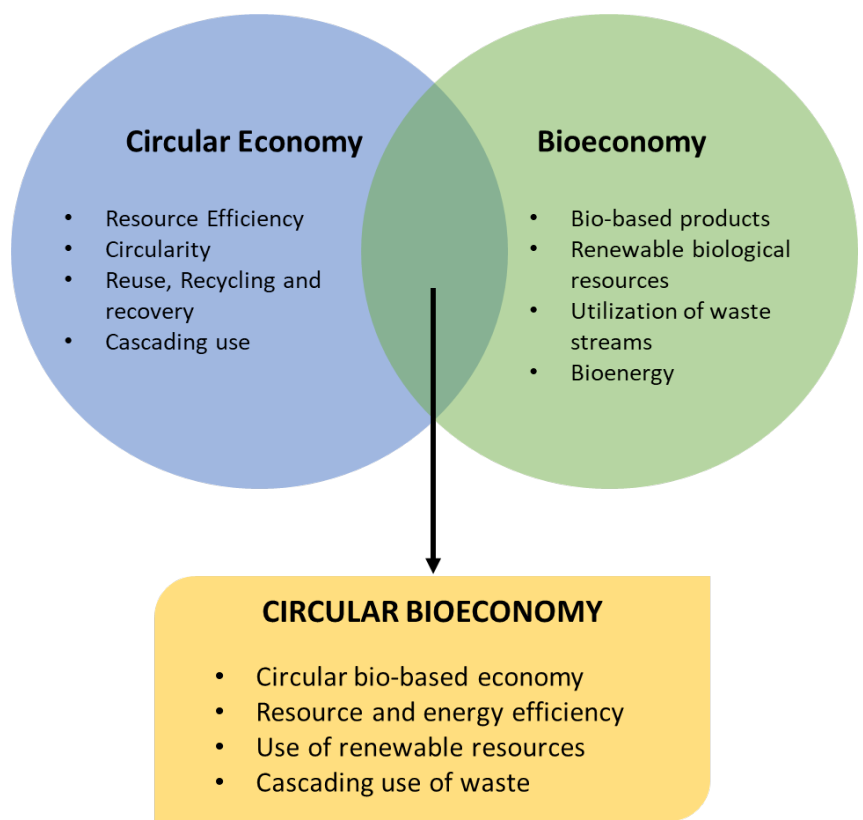

Fig. 1. Circular Bioeconomy concept based on Review of the EU bioeconomy strategy and its action plan [51].

Given the scope of this article, CBE can be defined as a "circular bio-based economy that works towards a greater resource and energy efficiency, these resources are biological and renewable, such as biowaste, which is recovered and reused through a cascading use, increasing as much as possible the life cycle of these products."

Applying this economic model (CBE) in a FVPI could enable energy and resources reutilization by maximizing circularity at its fullest. In order to better comprehend how this model can improve energy systems a careful analysis of energy supply and consumption data must be performed.

\section{Total Energy Supply}

To address global energy-related challenges, energy systems will need to go through a Clean Energy Transition (CET). An effective CET is a timely transition towards a more inclusive, sustainable, affordable, and secure energy system through cleaner sources and technology that provides solutions while creating value for economy, environment and society [10].

Given the complexity of energy systems, official entities have set long-term roadmaps and objectives [52], [53]. To comprehend the progress in achieving these objectives, the most up to date data regarding the world's and EU-28's TES from NRES and RES, scenarios and projections needs to be analyzed. This analysis will also posteriorly allow the assessment of the Industry sector's impact on energy systems and how they can contribute and benefit from the CET.

Based on data available on IEA's World Energy Balances database [54] the world's TES in 2018 was approximately 14280 Mtoe, of which $86 \%$ comes from NRES (Coal, Oil, Natural Gas and Nuclear) and 14\% comes from RES (Hydro, Wind, Solar, etc. and Biofuels and Waste (Biofuels and waste includes solid biofuels, biogases, liquid biofuels, industrial waste and municipal waste).

There is still a high percentage of energy sourced from coal $(27 \%)$ which has a crucial role in the industry sector. When comparing with other energy sources, coal is the highest $\mathrm{CO}_{2}$ emitter regarding the emissions from fuel combustion. Combining these aspects with the fact that only a small percentage of energy is coming from RES in 2018, greater concerns could be raised regarding the achievability of the Paris Agreement GHG emissions reduction target for 2050. If there is not an investment and commitment from all countries to increase shares of RE in each country's energy system it could result in a major setback globally [54], [55].

Focusing only on the EU geographical area, the EC has set an ambitious target of at least $32 \%$ of energy to be supplied by RES by 2030 will drive an acceleration of clean energy commitment in all sectors and therefore leveraging a swift CTE [56].

The TES in the EU-28 for 2010 and 2018 was 1729 and 1630 Mtoe respectively, which translates in a 5.7\% decrease. Concerning the NRES, although Oil share increased 1\% whereas shares of Coal and Natural Gas decreased 2\% and Nuclear 1\% since 2010. On the other hand, RES share grew from $11 \%$ to $15 \%$ ( $4 \%$ growth in 8 years), thereby if this growth tendency is maintained, the EC energy targets will not be achieved by 2030 .

In the IEA's 2020 Renewables Information: Overview Statistical Report, in 2018 the world's TES was 14280 Mtoe, of which 14\% was from RES [57].

Biofuels and waste have the largest share of the world's RE supply (66.4\%), mainly due to the use of solid biofuels/charcoal (58.9\%), mostly in developing countries for residential heating and cooking, the remaining share concerns liquid biofuels and biogases. The second largest source of RE is hydropower with $18.8 \%$.

A positive aspect is that since 1990, RES has grown at an average annual rate of $2.0 \%$, which is slightly higher than world's TES growth rate of $1.8 \%$.

This growth has been particularly high for solar PV and wind power with $36.5 \%$ and $23 \%$ annual growth respectively (Fig. 2). Solar thermal has a growth rate of $10.9 \%$. In countries where resources (sun and wind) and accessible financing are available, wind and solar PV plants will challenge existing fossil fuel industry. Solar projects in particular, now offer the lowest-cost electricity in history [58].

Biogases, including that from anaerobic digestion (AD), has the third highest growth rate at $11.5 \%$, followed by liquid biofuels $(9.7 \%)$.

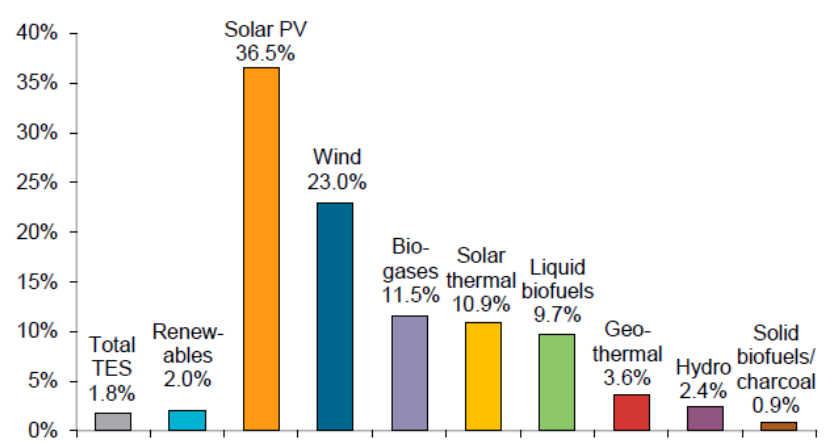

Fig. 2. Average annual growth rates of world renewables supply from 1990 to 2018 adapted from IEA (2020). Renewables Information: Overview 2020. All rights reserved. 
Pertaining only to the EU-28, from 1990 to 2018 (Fig. 3), the RE share went through considerable change. In 1990 the RES were mainly hydro, solid biofuels and renewable municipal waste (obtained from biodegradable fraction of municipal waste) corresponding to a TES of 72.18 Mtoe.

From that year to 2018 this sector increased $70 \%(72.18$ Mtoe to 242.14Mtoe with new RES appearing and contributing for this increase.

Also, wind and bioenergy (solid biofuels, liquid biofuels, renewable municipal waste, and biogas) are the sources of energy that experienced the highest increase, making up to $74 \%$ of all renewable energy sources in 2018 .

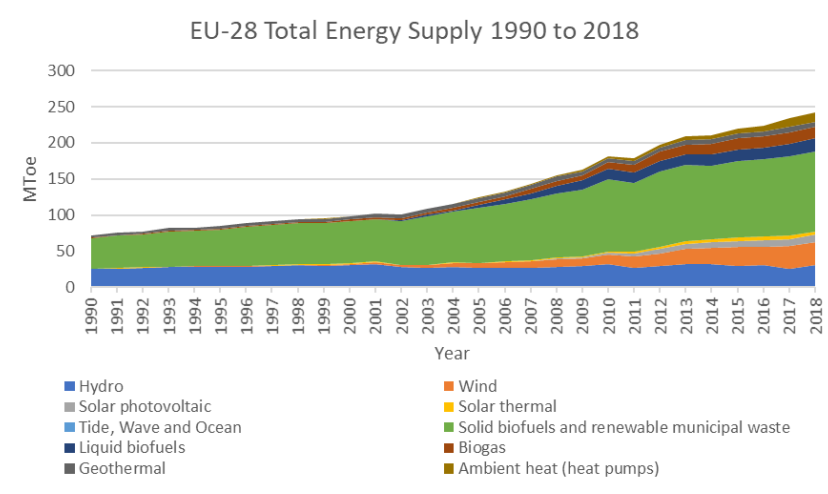

Fig. 3. EU-28 Total Energy Supply by Source 1990 and 2018 in Mtoe - Based on Energy statistical datasheets European Union Open Data Portal [59].

Through this analysis it is possible to see how much the RE sources became a key asset in the energy sector in EU-28 with an exponential growth since 1990. But it is important to commit and accelerate this transition through innovative energy solutions, so that the targets set by the EU are achieved by 2030 and consequently GHG emissions related to energy consumption are reduced.

Biogas and biomethane have been considered promising biofuels that can use renewable sources as feedstock, such as biowaste. Providing an analyses and insights on the most up to date, the overall potential and data and trends for 2030 and 2040 under different scenarios for these specific biofuels could help to better understand the role of these biofuels in the overall energy transition.

Recently the IEA released the "Outlook for biogas and biomethane: Prospects for organic growth" [60]. This report provides estimations of the sustainable potential for biogas and biomethane supply and projections on different scenarios for 2030 and 2040, based on the scenarios presented in the annual World Energy Outlook [61]. IEA's analysis includes only the technical potential of feedstock that can widely be considered sustainable. This is defined as "feedstocks that can be processed with existing technologies, which do not compete with food for agricultural land and that do not have any other adverse sustainability impacts (e.g., reducing biodiversity)", therefore designating it as: "sustainable bioenergy potential".

Fig. 4 presents the 2018 biogas and biomethane production against the sustainable potential globally. This analysis considers feedstocks that include crop residues, animal manure, municipal solid waste, wastewater and for gasification forestry residues.

Regarding the biomethane potential, the report considers two main production pathways: upgrading biogas and the gasification of biomass. For biogas upgrading, the same feedstocks assessed for biogas have been considered, on the assumption that these can be used either for biogas production or for upgrading biogas to biomethane. The second pathway to biomethane production is gasification which uses two additional sources of solid biomass feedstock: forestry residues and wood processing residues.

It can be observed that there is a huge potential that is not being explored. Biogas and biomethane production in 2018 were roughly 35 million Mtoe, only a fraction of the estimated overall potential. Full utilization of the sustainable potential could cover some $20 \%$ of today's worldwide gas demand [60].

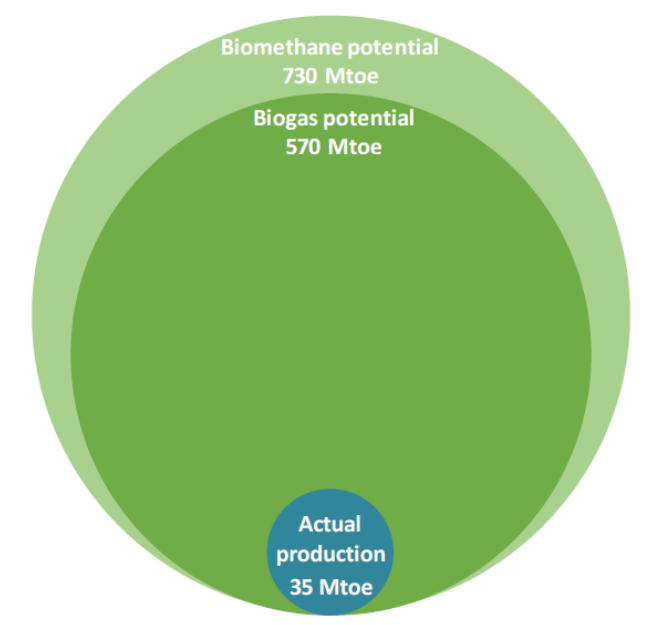

Fig. 4. Biogas and biomethane production in 2018 against the sustainable potential adapted from IEA (2020). Outlook for Biogas and Biomethane. World Energy Outlook Special Report. All rights reserved.

Focusing only on biogas, Fig. 5 shows that in 2018, Europe (EU group region, Albania, Belarus, Bosnia and Herzegovina, North Macedonia, Gibraltar, Iceland, Israel, Kosovo, Montenegro, Norway, Serbia, Switzerland, Republic of Moldova, Turkey, and Ukraine) was leading the way on biogas production with roughly 18 Mtoe, mostly from crops (which includes energy crops, crop residues and sequential crops) followed by animal manure, municipal solid waste, and municipal wastewater.

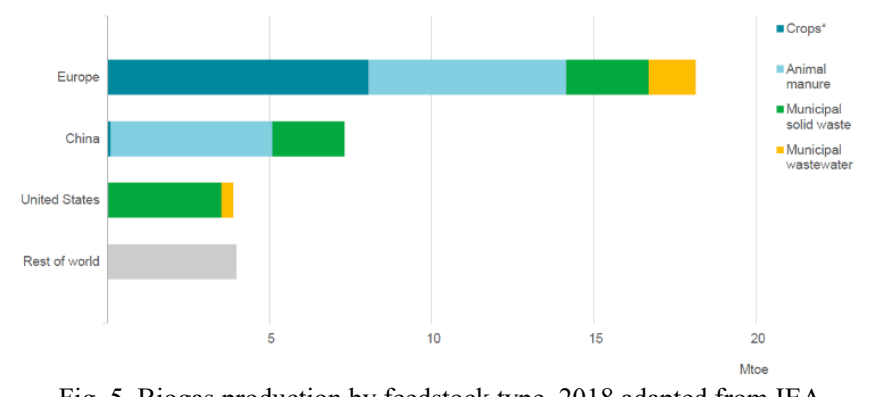

Fig. 5. Biogas production by feedstock type, 2018 adapted from IEA (2020). Outlook for biogas and biomethane: Prospects for organic growth. All rights reserved.

Municipal solid waste (which includes some industrial waste from food processing industry (FPI)) is the third highest feedstock for biogas production. Given that industrial waste is the highest-yielding feedstock, able to provide 
around 0.40 toe of energy per tonne [60], it suggests that there is an unexplored potential regarding the use of this feedstock and therefore there is a special interest in the industrial sector for biogas production.

There is a vast range of possible outcomes for global energy systems, which depend on technological innovation, the ambition of energy policies, market progress, societal trends, and several other factors.

Therefore, it is essential to give an insight on how biogas demand will evolve through 2030 and 2040 under different scenarios and consequently its potential compared with other types of bioenergy. This analysis could contribute to better understand how biowaste's producing industries could contribute to supply biogas's demand in the future and ultimately contribute for a CET.

Regarding projections for 2030 and 2040, the Outlook for Biogas and Biomethane Report [60] focuses on two scenarios: the Stated Policies Scenario (STEPS) and the Sustainable Development Scenario (SDS) that are described in the IEA's 2019 World Energy Outlook as:

-The Stated Policy Scenario (STEPS) "reflects the impact of existing policy frameworks and today's announced policy intentions. The aim is to hold up a mirror to the plans of today's policy makers and illustrate their consequences for energy use, emissions and energy security."

-The Sustainable Development Scenario (SDS) "maps out a way to meet sustainable energy goals in full, requiring rapid and widespread changes across all parts of the energy system. This scenario charts a path fully aligned with the Paris Agreement by holding the rise in global temperatures to "well below $2^{\circ} \mathrm{C} \ldots$ and pursuing efforts to limit [it] to $1.5^{\circ} \mathrm{C}$ ", and meets objectives related to universal energy access and cleaner air." [62]

Fig. 6 shows that global biogas and biomethane start from a low base but are the fastest developing types of bioenergy. Biogas demand globally in a STEPS scenario will increase $76 \%$ (36 Mtoe to 150 Mtoe) from to 2018 up to 2040 . For the SDS scenario biogas production will have a greater increase $89 \%$ (36 Mtoe to 325 Mtoe) by 2040.

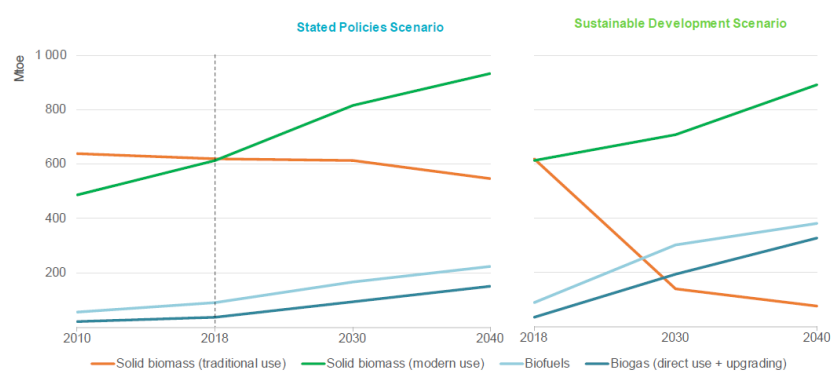

Fig. 6. Global bioenergy demand by scenario adapted from IEA (2020). Outlook for biogas and biomethane: Prospects for organic growth. All rights reserved.

It is clear that biogas and biomethane have a huge untapped potential and with the appropriate policies and investments there could be a rapid technological growth and consequently a production increase, improving waste management but also leverage the energy transition by 2050 .

\section{ENERGY CONSUMPTION IN THE INDUSTRY SECTOR}

After analyzing the TES, it is important to analyze in which sector this energy is consumed and from what energy sources. Given the scope of this article, the focus will be on the industry sector, particularly the food industry which includes FVPI. This analysis will help understand if this sector could be a key player for the CET in EU-28.

Based on data from the EC regarding the Final Energy Consumption (FEC) by sector in the EU-28 [63], in 2018 the Industry Sector (including FPI) accounted for $25 \%$ of the FEC (263.6 Mtoe), being the Transport Sector the highest final energy consumer (328.6 Mtoe) followed by Households (283.2 Mtoe).

Therefore, the industry sector can be identified as an essential element to tackle the high energy consumption and help meet the energy transition goals.

This sector includes several subsectors that are quite different from each other. The top four energy consumers were Chemical and Petrochemical 20\% (52.6 Mtoe), Nonmetallic minerals 14\% (36.2 Mtoe), Paper, Pulp \& Printing $13 \%$ (33.8 Mtoe), and the Food, Beverages, and Tobacco $12 \%$ (30.5 Mtoe) industries.

Considering the significance of Food, Beverage, and Tobacco industry, it is important to analyze the type of energy sources and how much they account for in this subsector.

This industry uses a wide range of technologies designed to make the final products safe, stable, and desirable by the consumer. These technologies are used in several processes such as heating, cooling, freezing, trituration, highpressuring, etc., leading to energy consumption along the production steps [64]-[66].

The FEC by energy source in the EU-28, in 2018 the highest sources of energy were natural gas which accounts for $47 \%$ and Electricity (mix of NRE and RE) for 34\%. Only 4\% of the FEC derives from Renewables and Biofuels.

With such low percentage of RES, it could be valuable to evaluate the applicability of RET in food industry, to increase the share of RE in the FEC.

Campiotti et al. [67] studied the energy consumption in several FVPI in the Mediterranean region. In these industries, the energy consumption accounts mainly for electricity used by the process of cooling and refrigeration, heating for both treatments and for infrastructure buildings, and thermal energy for hygiene and sterilization.

Based on this study, Table 1 lists the more common industrial processes in a FVPI, and report all energy related consumptions, distinguished in electricity, thermal energy, and electricity for water pumping. In total a FVPI plant consumes $427 \mathrm{kWh}$ per ton of processed product.

According to the latest FoodDrinkEurope report [68], in the EU $99,2 \%$ of the companies in the food and drinks sector are small and medium enterprises.

Therefore, assuming that in a medium-scale FVPI plant around 50000 tons per year of F\&V are processed [69] and that according to Caldeira et al. [70] 66\% of the total input is converted into product, 33,000 tons of processed product would be generated. As a result, the energy needs in this plant would be around 14.1 GWh per year. 
TABLE I: MAIN TRANSFORMATION PROCESSES IN A FVPI AND THEIR AVERAGE ENERGY CONSUMPTION IN KWH PER TON OF PROCESSED PRODUCT (BASED ON [67])

\begin{tabular}{|c|c|c|c|}
\hline Transformation process & $\begin{array}{c}\text { Electrical } \\
\text { energy } \\
\text { (KWh/ton } \\
\text { processed } \\
\text { product) }\end{array}$ & $\begin{array}{l}\text { Thermal } \\
\text { energy } \\
\text { (KWh/ton } \\
\text { processed } \\
\text { product) }\end{array}$ & $\begin{array}{c}\text { Electricity } \\
\text { for water } \\
\text { pumping } \\
\text { (KWh/ton } \\
\text { processed } \\
\text { product) }\end{array}$ \\
\hline Raw material reception & 3.4 & - & - \\
\hline $\begin{array}{l}\text { Washing, sorting, and } \\
\text { sizing }\end{array}$ & 2.1 & 51 & - \\
\hline $\begin{array}{l}\text { Cutting, grinding, } \\
\text { calibration, peeling, etc. } \\
\text { After-treatment }\end{array}$ & 3.4 & 72 & 3 \\
\hline $\begin{array}{c}\text { operations, checking and } \\
\text { packaging }\end{array}$ & 3 & 50 & - \\
\hline $\begin{array}{l}\text { Heat treatment for } \\
\text { stabilization }\end{array}$ & - & 229 & 8 \\
\hline Cooling & 1.1 & - & - \\
\hline Storage & 1 & - & - \\
\hline Total energy & 14 & 402 & 11 \\
\hline
\end{tabular}

These energy needs could be partially met by implementing RET in the FVPI plant to produce energy for self-consumption, therefore, a data assessment and a deeper examination of these industries is critical to understand the potential of converting biowaste into bioenergy and at the same time maximizing circularity.

\section{BIOWASTE PRODUCTION IN FOOD INDUSTRY}

Along the production processes that take place in a FVPI different type of wastes are generated [71]. This article will focus on biowaste.

There are many definitions for biowaste and FW [72], and the most suitable biowaste definition in the context of this article is from the European Commission [73]: "Bio-waste is defined as biodegradable garden and park waste, food and kitchen waste from households, restaurants, caterers and retail premises, and comparable waste from food processing plants. It does not include forestry or agricultural residues, manure, sewage sludge, or other biodegradable waste such as natural textiles, paper or processed wood. It also excludes those by-products of food production that never become waste."

And for FW definition, Stenmarck et al. [5] defines as "Fractions of 'food and inedible parts of food removed from the food supply chain' to be recovered or disposed (including - composted, crops ploughed in/not harvested, anaerobic digestion, bioenergy production, co-generation, incineration, disposal to sewer, landfill or discarded to sea)."

About 88 million tonnes of food are wasted annually in the EU from primary production up to consumption, with associated costs estimated at 143 billion euros [5] and the FW rate is expected to rise if no action is taken. For this reason, the EC has identified FW as one of the top priority areas of the European Circular Economy Action Plan.

FW can be valorized by being transformed into biomaterials or bioenergy, through cascade use for example, which contributes to bioeconomy and simultaneously to closing the loop of food systems while reducing environmental impacts and helping social developing [74].

In a study by Caldeira et al. [70], the total amount of FW
(Meat, Fish, Dairy, Eggs, Cereals, Fruit, Vegetables, Potatoes, Sugar beets, and Oil Crops) along the food supply chain in EU-28 (Primary Production, Processing \& Manufacturing, Retail \& Distribution and Consumption) was 129.2 Mt. Around 24\% (30.6Mt) of this waste occurred in the Processing \& Manufacturing stage, providing an opportunity and potential to implement waste circularity.

The highest amounts of FW waste, in Processing \& Manufacturing stage, are the Oils Crops (10 Mt), Fruit (6.1 $\mathrm{Mt})$, Fish (3.1Mt), Meat (2.9 Mt) and Vegetables (2.6 Mt).

Supplementary data from Caldeira et al. [70] shows more detailed data of FW production in Processing \& Manufacturing stage. From a total of $68.2 \mathrm{Mt}$ of Fruit \& Vegetables $(\mathrm{F} \& \mathrm{~V})$ entering as input raw material, approximately $28 \%(18.8 \mathrm{Mt})$ is rejected as fruit and vegetables waste (FVW), making this biowaste interesting regarding quantities and availability.

Taking this into account, converting FVW into bioenergy has a real potential to increase circularity while producing RE. From the several RET, AD can be an attractive option by using FW as feedstock to produce biogas consequentially converted into energy [75], [76].

In section IV of this review, we analyzed projections regarding the production of biogas, therefore it is also important to analyze projection regarding FVW generation to better understand its future potential use and contribution for biogas production.

Considering that no data or relevant studies about projections for FW by type were found, we used projections data from the International Food Policy Research Institute [77] for food production by commodities. Table 2 shows the projections for the total production (million metric tonnes) of Cereals, Meat, F\&V, Oilseeds, and Roots and Tubers, in EU28 for 2030 and 2050. Results are shown for two "baseline" scenarios "without climate change" and "with climate change" - one considers the impacts of climate change, whereas the other assumes no climate change (for comparison) [78].

TABLE II: TOTAL PRODUCTION BY COMMODITY IN EU-28 FOR 2030 AND 2050 UNDER TWO SCENARIOS BASED ON INTERNATIONAL FOOD POLICY RESEARCH INSTITUTE (IFPRI), 2019, WITH AND WITHOUT CLIMATE CHANGE

\begin{tabular}{ccccc}
\hline \hline & \multicolumn{2}{c}{ Total production (million metric tons) } \\
\cline { 2 - 5 } & \multicolumn{2}{c}{$\begin{array}{c}\text { Without climate } \\
\text { change }\end{array}$} & \multicolumn{2}{c}{$\begin{array}{c}\text { With climate } \\
\text { change }\end{array}$} \\
\cline { 2 - 5 } & 2030 & 2050 & 2030 & 2050 \\
\hline Cereals & 304 & 318 & 301 & 323 \\
Meat & 50 & 54 & 50 & 53 \\
Fruit \& Vegetables & 200 & 246 & 188 & 216 \\
Oilseeds & 52 & 59 & 51 & 56 \\
Pulses & 7 & 8 & 7 & 8 \\
Roots and Tubers & 73 & 77 & 68 & 66 \\
\hline
\end{tabular}

In both scenarios it can be observed that up to 2050 Cereals, F\&V and Roots and Tubers are the top three commodities to be produced in terms of quantities.

As projections indicate an increase in the production of $\mathrm{F} \& \mathrm{~V}$, an increase in FVW production is expected. Based on Caldeira et al. [70], approximately $51 \%$ of $\mathrm{F} \& \mathrm{~V}$ production is forwarded to Processing \& Manufacturing stage and approximately $28 \%$ from this input of raw material is converted into FVW. This means that according to the 
projections for 2050, "without climate change" and "with climate change", around $38 \mathrm{Mt}$ and $31 \mathrm{Mt}$ of FVW will be produced, respectively. These amounts of FVW are considerable and therefore FVPI could benefit from converting FVW into bioenergy.

In general, chemical, and physical characteristics of FVW have a high content of water and biodegradable compounds, with $8-18 \%$ total solids (TS) and $86-92 \%$ of total volatile solids (VS) content. The organic composition includes about $75 \%$ easy biodegradable matter (sugars, carbohydrates, lipids, and proteins), 9\% cellulose and 5\% lignin [79], [80]. These characteristics show that FVW is suitable for AD [75], [81]-[83].

$\mathrm{AD}$ is a useful and excellent process that can convert waste into valuable material and energy. There are several benefits related to the AD process such as decreased GHG emission, production of digestate for application in agriculture and the generation of high-quality renewable fuel (biogas). Digestate can have fertilizing or amending properties due to its nutritive characteristics. Digestate contains various kinds of organic matters $(\mathrm{C})$, macronutrients $(\mathrm{N}, \mathrm{P})$ and micronutrients $(\mathrm{K}, \mathrm{Na}$, $\mathrm{Ca}$, and others), which have the potentials for agricultural valorization and consequently increasing circularity within the biogas production system [84], [85].

The AD is a multi-step biochemical process that can be divided into four stages i.e., hydrolysis, acidogenesis, acetogenesis, and methanogenesis. In the $\mathrm{AD}$ procedure, various kinds of bacteria degrade the organic substance continuously in different stages via parallel reactions. There are several factors that influence bacteria performance and consequently biogas production.

Biogas production is highly influenced by temperature. The AD process can take place at various temperatures, which are normally classified into three types, i.e., psychrophilic, mesophilic, and thermophilic temperatures. The mesophilic and thermophilic temperature ranges are between $20-40{ }^{\circ} \mathrm{C}$ and $50-65{ }^{\circ} \mathrm{C}$, respectively. A lower temperature reduces $\mathrm{FW}$ degradation rates and bacterial development, consequently decreasing biogas production [75].

An alternative to $\mathrm{AD}$ is anaerobic codigestion (AcoD), which is the simultaneous digestion of two or more different substrates as feedstock. Mixing the carbon-rich and nitrogen rich substrates, such as manure and FVW, can improve process stability, nutrients for microorganisms and biogas production. [86], [87].

Several authors [88]-[90] have analyzed the co-digestion of different substrates (mixed sewage sludge, cow manure and poultry manure) with FVW and concluded that it improved the microbial consortium and consequently increased the biogas yield, when compared to monodigestion.

The process of AcoD using FVW and other substrates is a very interesting waste management solution. Therefore, more studies on this topic should be developed, regarding substrates and their availability in FVPI, pre-treatments and other factors that influence the AcoD process aiming to increase the quality and quantity of biogas and digestate, consequently improving the whole circular cycle. The possible integration of AcoD and other RET is worth analyzing.

\section{RENEWABLE TECHNOLOGIES INTEGRATION}

In this section, two conceptual model approaches for Agrifood system are suggested and analyzed, a conventional energy system (CoES) (as the reference one) and an integrated renewable energy system (IRES). Fig. 7 and 8 illustrate the two different conceptual approaches, presenting the inputs, processes, and outputs.

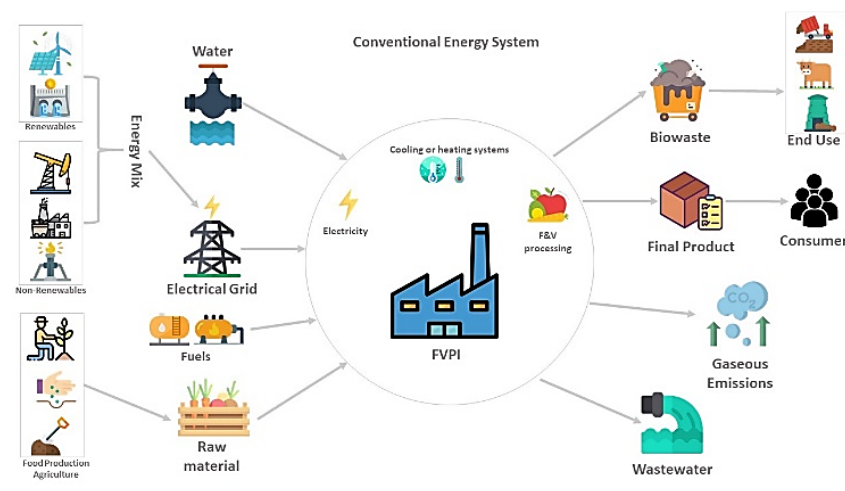

Fig. 7. Conventional Energy System (based on Sims et al. [66]). Icons made by Freepik from www.flaticon.com.

Fig. 7 shows that a mix of RES and NRES (mostly NRES) supply the electrical grid and posteriorly is consumed by FVPI. It is possible to observe that this CoES is linear from an energy and waste perspective and that by applying RET in a strategic and integrative vision would increase energy and waste circularity assisted by a CBE approach. Therefore, combining the integration of RET and a CBE business model could lead to a more economical and environmental resilient sustainable system.

Taking this into account, it is essential to rethink how industrial systems should be designed or redesigned in the future to minimize NRE shares, resource consumption and negative environmental impact. To overcome these challenges Fig. 8 proposes the design of an IRES, with an integrative and harmonious approach aiming to increase the percentage of RE self-consumed in the FVPI.

From the several RET we chose to focus on the AcoD and solar energy (PV and ST) integration. Solar energy is suitable and effective for industrial processes and AcoD, as discussed in section VI, given process characteristics and biowaste produced in the FVPI is also a good technological option [22], [91]. Only few authors mention the integration of these technologies [92], [93] therefore discussing this proposed approach within the academic and industry community could open the way to discussion on its possible advantages and constraints.

In Fig. 8, it can be observed that in the energy input there is still a percentage of energy mix (RE and NRE). To increase the RE shares self-consumed by the FVPI, installing PV panels will provide electricity to be used directly on equipment and processes. ST panels can also be integrated to provide cooling or heating systems or heat for the anaerobic digester. During $\mathrm{AD}$ it is necessary to keep an optimal temperature regime, which can be achieved with assistance of ST technology [94], [95].

The biowaste, instead of the typical end-uses, can be reintroduced in the system as co-substrate for AcoD, combined with a substrate such as manure or activated 
sludge, producing biogas and digestate. The digestate can be valorized as a fertilizer in agriculture, closing the circular loop from the waste perspective. The biogas can be converted into electricity and heat through a cogeneration process, using the heat to warm the digester to its optimal temperature during mesophilic or thermophilic phase. The electricity produced from cogeneration, would be directed to the electrical grid.

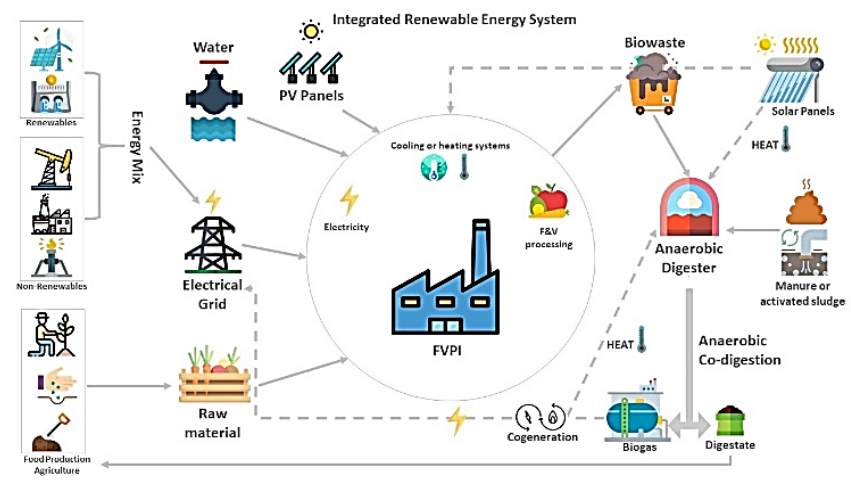

Fig. 8. Integrated Renewable Energy Systems Scenario (based on Smith [92] and Gaballah et al. [93]). Icons made by Freepik from www.flaticon.com.

From a holistic view, this IRES conceptual model is in accordance with a CBE business model, discussed in section III. The levels of circularity and RE achieved with this conceptual model, allow for a greater resource efficiency, share of RE in consumption and biowaste management which will consequently create economic and social value and positive impacts in the environment. Ultimately, it helps the system to become more resilient and less dependent in all the three sustainability pillars.

Focusing on the integration PV and ST as suggested above, a technological solution for this integration could be the use of hybrid photovoltaic-thermal (PVT) solar collectors, which over the last years have been investigated and discussed. Incorporation of solar PV with the ST collectors allows simultaneous generation of electricity and heat, being more efficient and producing higher amount of energy per unit area, i.e., with the same area, PVT collectors can generate more heat and electricity than that produced by conventional PV or ST collectors [22], [96]-[100].

Bianchini et al. [101] studied the potential offered by hybrid PVT solar system in Central Italy, using a commercial PVT solar plant at the "HEnergia" outdoor development center in Forlì (Italy). The best results showed that the hybrid PVT solar system can produce annually about $66.6 \mathrm{kWh} / \mathrm{m}^{2}$ of electricity whereas the heat generation was $443 \mathrm{kWh} / \mathrm{m}^{2}$.

In a study by Herrando et al. [102], the authors assess an alternative solar system based on hybrid PVT collectors coupled with an absorption chiller in a FVPI plant in the Mediterranean area. The authors found that the optimum number of PVT collectors had a range of between $20\left(32 \mathrm{~m}^{2}\right)$ and $240\left(386 \mathrm{~m}^{2}\right)$. In this review we will consider the maximum number of collectors (240) since the FVPI plant's energy consumption reported by the authors is much lower than the assumed in section $\mathrm{V}$.

Considering the Bianchini et al. [101] and Herrando et al. [102] studies, the theoretical annual electrical and thermal output of the PVT solar system would be $24.7 \mathrm{MWh}$ and
170.1 MWh, respectively. This electrical energy could be used directly in the FVPI plant and the thermal energy could be used either in the plant or to heat the AcoD reactor. The energy outputs can be augmented by increasing the number of PVT collectors depending on the FVPI plant energy needs.

As mentioned in section $\mathrm{V}$, in a medium-scale FVPI plant around 50,000 tons per year of F\&V are converted into 33,000 tons of processed product and 14,000 tons of FVW. Assuming this plant only processes apples and the waste output is apple pomace (AP), according to a study by Perimenis et al. [103] in which the authors determined the methanogenic potential of different agro-industrial wastes utilizing activated sludge as inoculum in batch conditions, the methane production for AP is $84.70 \mathrm{mLCH} 4 / \mathrm{g} \mathrm{AP}$. Considering this study was performed in lab-scale and batch conditions, the above mentioned value may not reflect the reality of a full scale scenario, therefore in this review we assume only for $70 \%$ of the methane production value presented in the study. Considering that 14,000 tons of AP are produced per year, with the assumption mentioned above, the methane production would be around $830,068 \mathrm{~m}^{3} \mathrm{CH}_{4} /$ year.

The methane produced can be converted into energy (electrical and thermal) through a cogeneration system. Dalpaz et al. [104] evaluated the electric and thermal energy generated in a cogeneration system, using biogas produced by the $\mathrm{AD}$ of agro-industrial waste. In this study the authors concluded that this cogeneration system could provide $7.77 \mathrm{kWh} / \mathrm{m}^{3}$ of energy (electrical and thermal combined). Applying these results to our plant example, it would be possible to generate $6.5 \mathrm{GWh} /$ year from the $830,058 \mathrm{~m}^{3} \mathrm{CH}_{4}$ produced.

Therefore, the proposed IRES would be able to produce a total of $6.7 \mathrm{GWh} /$ year of RE using hybrid PVT collectors and AcoD, accounting for $48 \%$ of the FVPI plant's processing energy needs.

The data discussed above regarding the several technologies and processes involved in IRES conceptual model may vary if applied in full scale or if operational efficiency is improved, a full detailed energy balance assessment to maximize the benefits of this integration is crucial. Furthermore, a theoretical economic viability assessment should be performed, nevertheless it is important to have energy indicators based on recent studies and available data.

Regarding the whole food industry sector, if this IRES conceptual model could be applied in companies across the sector, it could provide a significant contribution towards achieving the EC's target of at least $32 \%$ of energy to be supplied by RES by 2030 and inspire other sectors to implement a similar model adapted to their specific characteristics.

Since the essence of both IRES conceptual model and CBE business model is similar i.e., both intend to increase circularity flows within the system, implementing them together in a complementary way not only could increase RE production and biowaste reintegration, but it could also promote economic growth and competitiveness advantage by establishing a circular bio-based economy as a main asset in this business model.

There are a limited number of studies or data regarding the implementation of these technologies in FPI or FVPI. Hence, 
we strongly suggest and support establishing synergies between industries and academic institutions to develop studies on this research topic.

\section{Conclusion And Future Perspectives}

As seen through the systematization and analysis of the energy data carried out, the energy transition goals can be achieved by 2030 not only by increasing RES but also by decreasing energy consumption. These two action areas can be developed by robust renewable energy policies and financial investments allowing energy systems to become more resilient and sustainable. Further debate and analysis of RE systems between different stakeholders could help accelerate a CET.

Industry is one of the largest energy consumption sectors. Inside this sector we focused on FVPI, due to its unique features from an energy consumption and biowaste production perspective. During this literature research a lack of data regarding biowaste production especially in food industry was identified, i.e., no updated quality data was available. This limitation greatly affects the assessment of the true potential and viability to convert biowaste into bioenergy in FVPI.

To overcome many of the challenges identified throughout this review, the proposed IRES conceptual model increases the sources of renewable energy and allows to close the circular loop by using FVW in AcoD and by-products from this process. There were very few studies performed regarding the mix of RET (PV, ST and AcoD), therefore it is important to do a full assessment concerning RE production potential and economic viability.

Regarding the business models that can promote the adoption of RES in FPI, this article proposes a definition for the three key concepts: CE, BE and CBE.

It is important to mention that due to the Covid-19 pandemic the economy has been greatly affected and consequently, depending on how the economic recovery will progress, the energy transition could be impacted positively or negatively. This transition could be limited and not achievable due to the lack of investment and policies in renewable energy technology. If a green economic recovery takes place the energy transition targets could be successfully reached by focusing investments on renewable energy sources and policies to reduce energy consumption.

\section{ACKNOWLEDGMENT}

The authors would like to thank www.flaticon.com for the permission to use Icon made by Freepik in this article. Special thanks to Alan Lewis for the English proofreading.

\section{REFERENCES}

[1] World Bank, "Population Estimates and Projections," 2019. https://datacatalog.worldbank.org/dataset/population-estimates-andprojections (accessed Aug. 28, 2019).

[2] FAO, "The future of food and agriculture: Trends and challenges.," 2017. [Online]. Available: http://www.fao.org/3/i6583e/i6583e.pdf.
[3] FAO, "The Future of Food and Agriculture Alternative Pathways to 2050," 2018. [Online]. Available: http://www.fao.org/3/I8429EN/i8429en.pdf.

[4] S. Kaza, L. C. Yao, P. Bhada-Tata, and F. Van Woerden, What a Waste 2.0: A Global Snapshot of Solid Waste Management to 2050. Washington, DC: Washington, DC: World Bank, 2018.

[5] Å. Stenmarck et al., "Estimates of European food waste levels," 2016. [Online]. Available: https://www.eufusions.org/phocadownload/Publications/Estimates of European food waste levels.pdf\%5Cnhttps://phys.org/news/2016-12-quarter-milliontonnes-food-logistics.html\#nRlv.

[6] H. V. Singh, R. Bocca, P. Gomez, S. Dahlke, and M. Bazilian, "The energy transitions index: An analytic framework for understanding the evolving global energy system," Energy Strateg. Rev., vol. 26, p. 100382, 2019, doi: https://doi.org/10.1016/j.esr.2019.100382.

[7] X.-C. Yuan, Y.-J. Lyu, B. Wang, Q.-H. Liu, and Q. Wu, "China's energy transition strategy at the city level: The role of renewable energy," J. Clean. Prod., vol. 205, pp. 980-986, Dec. 2018, doi: 10.1016/j.jclepro.2018.09.162.

[8] Q. Wang and S. Wang, "Is energy transition promoting the decoupling economic growth from emission growth? Evidence from the 186 countries," J. Clean. Prod., vol. 260, p. 120768, Jul. 2020, doi: 10.1016/j.jclepro.2020.120768.

[9] S. Tagliapietra, G. Zachmann, O. Edenhofer, J.-M. Glachant, P. Linares, and A. Loeschel, "The European union energy transition: Key priorities for the next five years," Energy Policy, vol. 132, pp. 950954, Sep. 2019, doi: 10.1016/j.enpol.2019.06.060.

[10] R. Bocca, "Fostering Effective Energy Transition. 2020 edition.," 2020. [Online]. Available: www.weforum.org.

[11] European Commission, "Communication from the Commission to the European Parliament, the European Council, the Council, the European Economic and Social Committee and the Committee of the Regions the European Green Deal COM/2019/640 final,” 2019.

[12] European Commission, "Communication from the Commission to the European Parliament, the European Council, the Council, the European Economic and Social Committee and the Committee of the Regions A New Industrial Strategy for Europe COM/2020/102 final," 2020. [Online]. Available: https://ec.europa.eu/info/sites/info/files/communication-eu-industrialstrategy-march-2020_en.pdf.

[13] J. Korhonen, C. Nuur, A. Feldmann, and S. E. Birkie, "Circular economy as an essentially contested concept," J. Clean. Prod., vol. 175, pp. 544-552, Feb. 2018, doi: 10.1016/j.jclepro.2017.12.111.

[14] EFM, "Ellen MacArthur Foundation," 2020. https://www.ellenmacarthurfoundation.org/ (accessed Dec. 02, 2020).

[15] D. D'Amato et al., "Green, circular, bio economy: A comparative analysis of sustainability avenues," J. Clean. Prod., vol. 168, pp. 716734, Dec. 2017, doi: 10.1016/j.jclepro.2017.09.053.

[16] European Commission, "Innovating for Sustainable Growth: A Bioeconomy for Europe," Ind. Biotechnol., vol. 8, no. 2, pp. 57-61, Apr. 2012, doi: 10.1089/ind.2012.1508.

[17] Institute for European Environmental Policy, "Promoting a circular, sustainable bioeconomy - delivering the bioeconomy society needs," 2018. https://ieep.eu/news/promoting-a-circular-sustainablebioeconomy-delivering-the-bioeconomy-society-needs (accessed Oct. $13,2020)$.

[18] T. M. W. Mak, X. Xiong, D. C. W. Tsang, I. K. M. Yu, and C. S. Poon, "Sustainable food waste management towards circular bioeconomy: Policy review, limitations and opportunities," Bioresour. Technol., vol. 297, p. 122497, Feb. 2020, doi: 10.1016/j.biortech.2019.122497.

[19] S. Coderoni and M. A. Perito, "Sustainable consumption in the circular economy. An analysis of consumers' purchase intentions for waste-tovalue food," J. Clean. Prod., vol. 252, p. 119870, Apr. 2020, doi: 10.1016/j.jclepro.2019.119870.

[20] G. Garcia-Garcia, J. Stone, and S. Rahimifard, "Opportunities for waste valorisation in the food industry - A case study with four UK food manufacturers," J. Clean. Prod., vol. 211, pp. 1339-1356, Feb. 2019, doi: 10.1016/j.jclepro.2018.11.269.

[21] N. Mirabella, V. Castellani, and S. Sala, "Current options for the valorization of food manufacturing waste: a review," J. Clean. Prod., vol. 65, pp. 28-41, Feb. 2014, doi: 10.1016/j.jclepro.2013.10.051.

[22] Y. Jia, G. Alva, and G. Fang, "Development and applications of photovoltaic-thermal systems: A review," Renew. Sustain. Energy Rev., vol. 102, pp. 249-265, Mar. 2019, doi: 10.1016/j.rser.2018.12.030.

[23] P. G. V. Sampaio and M. O. A. González, "Photovoltaic solar energy: Conceptual framework," Renew. Sustain. Energy Rev., vol. 74, pp. 590-601, Jul. 2017, doi: 10.1016/j.rser.2017.02.081.

[24] J. Kirchherr, D. Reike, and M. Hekkert, "Conceptualizing the circular economy: An analysis of 114 definitions," Resour. Conserv. Recycl., 
vol. 127, pp. 221-232, Dec. 2017, doi: 10.1016/j.resconrec.2017.09.005.

[25] M. Giampietro, "On the Circular Bioeconomy and Decoupling: Implications for Sustainable Growth," Ecol. Econ., 2019, doi: 10.1016/j.ecolecon.2019.05.001.

[26] F.-D. Vivien, M. Nieddu, N. Befort, R. Debref, and M. Giampietro, "The Hijacking of the Bioeconomy," Ecol. Econ., vol. 159, pp. 189197, May 2019, doi: 10.1016/j.ecolecon.2019.01.027.

[27] J. L. Cardoso, "The circular economy: historical grounds," in Changing societies: legacies and challenges. The diverse worlds of sustainability, Imprensa de Ciências Sociais, 2018, pp. 115-127.

[28] K. Winans, A. Kendall, and H. Deng, "The history and current applications of the circular economy concept," Renew. Sustain. Energy Rev., vol. 68, pp. 825-833, Feb. 2017, doi: 10.1016/j.rser.2016.09.123.

[29] J. Korhonen, A. Honkasalo, and J. Seppälä, "Circular Economy: The Concept and its Limitations," Ecol. Econ., vol. 143, pp. 37-46, Jan. 2018, doi: 10.1016/j.ecolecon.2017.06.041.

[30] K. Hobson, "Closing the loop or squaring the circle? Locating generative spaces for the circular economy," Prog. Hum. Geogr., vol. 40, no. 1, pp. 88-104, Feb. 2016, doi: 10.1177/0309132514566342.

[31] J. Singh and I. Ordoñez, "Resource recovery from post-consumer waste: important lessons for the upcoming circular economy," J. Clean. Prod., vol. 134, pp. 342-353, Oct. 2016, doi: 10.1016/j.jclepro.2015.12.020.

[32] V. Moreau, M. Sahakian, P. van Griethuysen, and F. Vuille, "Coming Full Circle: Why Social and Institutional Dimensions Matter for the Circular Economy," J. Ind. Ecol., vol. 21, no. 3, pp. 497-506, Jun. 2017, doi: 10.1111/jiec.12598.

[33] M. Haupt, C. Vadenbo, and S. Hellweg, "Do We Have the Right Performance Indicators for the Circular Economy?: Insight into the Swiss Waste Management System," J. Ind. Ecol., vol. 21, no. 3, pp. 615-627, 2017, doi: 10.1111/jiec.12506.

[34] M. Niero, M. Z. Hauschild, S. B. Hoffmeyer, and S. I. Olsen, "Combining Eco-Efficiency and Eco-Effectiveness for Continuous Loop Beverage Packaging Systems: Lessons from the Carlsberg Circular Community," J. Ind. Ecol., vol. 21, no. 3, pp. 742-753, Jun. 2017, doi: $10.1111 /$ jiec. 12554

[35] W. Haas, F. Krausmann, D. Wiedenhofer, and M. Heinz, "How Circular is the Global Economy?: An Assessment of Material Flows, Waste Production, and Recycling in the European Union and the World in 2005 ," J. Ind. Ecol., vol. 19, no. 5, pp. 765-777, Oct. 2015, doi: 10.1111 /jiec. 12244 .

[36] H. Wu, Y. Shi, Q. Xia, and W. Zhu, "Effectiveness of the policy of circular economy in China: A DEA-based analysis for the period of 11th five-year-plan," Resour. Conserv. Recycl., vol. 83, pp. 163-175, Feb. 2014, doi: 10.1016/j.resconrec.2013.10.003.

[37] S. Ma, S. Hu, D. Chen, and B. Zhu, "A case study of a phosphorus chemical firm's application of resource efficiency and eco-efficiency in industrial metabolism under circular economy," J. Clean. Prod., vol. 87, no. 1, pp. 839-849, Jan. 2015, doi: 10.1016/j.jclepro.2014.10.059.

[38] S. Ma, Z. Wen, J. Chen, and Z. Wen, "Mode of circular economy in China's iron and steel industry: a case study in Wu'an city," J. Clean. Prod., vol. 64, pp. 505-512, Feb. 2014, doi: 10.1016/j.jclepro.2013.10.008.

[39] J. Naustdalslid, "Circular economy in China - the environmental dimension of the harmonious society," Int. J. Sustain. Dev. World Ecol., vol. 21, no. 4, pp. 303-313, Jul. 2014, doi: 10.1080/13504509.2014.914599.

[40] F. Blomsma and G. Brennan, "The Emergence of Circular Economy: A New Framing Around Prolonging Resource Productivity," J. Ind. Ecol., vol. 21, no. 3, pp. 603-614, 2017, doi: 10.1111/jiec.12603.

[41] OECD, "Biomass for a Sustainable Bioeconomy: Technology and Governance. DSTI/STP/BNCT(2016)7,” 2016. [Online]. Available: https://one.oecd.org/document/DSTI/STP/BNCT(2016)7/en/pdf.

[42] Biooekonomierat, Combine Disciplines, Improve Parameters, Seek out International Partnerships. First Recommendations for Research into the Bio-Economy in Germany. 2009.

[43] M. Bugge, T. Hansen, and A. Klitkou, "What Is the Bioeconomy? A Review of the Literature," Sustainability, vol. 8, no. 7, p. 691, Jul. 2016, doi: 10.3390/su8070691.

[44] S. F. Pfau, J. E. Hagens, B. Dankbaar, and A. J. M. Smits, "Visions of sustainability in bioeconomy research," Sustain., vol. 6, no. 3, pp. 1222-1249, 2014, doi: 10.3390/su6031222.

[45] European Commission, "Review of the 2012 European Bioeconomy Strategy," 2017. doi: 10.2777/086770.

[46] European Commission, A sustainable Bioeconomy for Europe: strengthening the connection between economy, society and the environment. 2018.

[47] European Commission, "Sustainable and circular biobased economy, the European way," 2018. doi: 10.2777/159097.
[48] L. Hetemäki, M. Hanewinkel, B. Muys, M. Ollikainen, M. Palahí, and A. Trasobares, Leading the way to a European circular bioeconomy strategy. 2017

[49] S. Venkata Mohan, S. Dahiya, K. Amulya, R. Katakojwala, and T. K. Vanitha, "Can circular bioeconomy be fueled by waste biorefineries A closer look," Bioresour. Technol. Reports, 2019, doi: 10.1016/j.biteb.2019.100277.

[50] M. Carus and L. Dammer, "The Circular Bioeconomy-Concepts, Opportunities, and Limitations," Ind. Biotechnol., vol. 14, no. 2, pp. 83-91, Apr. 2018, doi: 10.1089/ind.2018.29121.mca.

[51] Directorate-General for Research and Innovation, "Review of the EU bioeconomy strategy and its action plan. Expert group report.," 2017. doi: $10.2777 / 149467$.

[52] IRENA, Global energy transformation: A roadmap to 2050 (2019 edition). 2019.

[53] European Commission, "Communication from the Commission to the European Parliament, the European Council, the Council, the European Economic and Social Committee, the Committee of the Regions and the European Investment Bank a Clean Planet for all A European strategic long-ter," 2018. [Online]. Available: https://eurlex.europa.eu/legalcontent/EN/TXT/?uri=CELEX\%3A52018DC0773.

[54] IEA, "[dataset] Extended world energy balances (Edition 2020). IEA World Energy Statistics and Balances (database)," 2020. https://www.oecd-ilibrary.org/content/data/88fdlacf-en (accessed Oct. 19, 2020).

[55] IEA, International Energy Agency Carbon Dioxide (CO2) Emissions from Fuel Combustion, 1751-2019. [data collection]. 13th Edition. 2020.

[56] Directorate-General for Energy (European Commission), "Clean energy for all Europeans," 2019. doi: 10.2833/9937.

[57] IEA, Renewables Information: Overview. OECD, 2020.

[58] IEA, "Renewables 2020. Analysis and forecast to 2025.," 2020. [Online]. Available: https://www.iea.org/reports/renewables-2020.

[59] European Commission, EU energy in figures Statistical pocketbook 2020.

[60] IEA, Outlook for Biogas and Biomethane: Prospects for Organic Growth. OECD, 2020.

[61] IEA, "World Energy Outlook 2019," World Energy Outlook 2019, [Online]. Available: https://www.iea.org/reports/world-energyoutlook-2019\%0Ahttps://www.iea.org/reports/world-energy-outlook2019\%0Ahttps://webstore.iea.org/download/summary/2467?fileName =Japanese-Summary-WEO2019.pdf.

[62] IEA, "World Energy Model 2019," Jan. 2019. Accessed: Nov. 18, 2019. [Online]. Available: https://www.iea.org/reports/world-energymodel.

[63] Eurostat, "[dataset] Energy Balances Database," Statistical Office of the European Union Luxembourg, 2020. https://ec.europa.eu/eurostat/web/energy/data/energy-balances (accessed Oct. 19, 2020).

[64] G. M. Hall and J. Howe, "Energy from waste and the food processing industry," Process Saf. Environ. Prot., vol. 90, no. 3, pp. 203-212, May 2012, doi: $10.1016 /$ j.psep.2011.09.005.

[65] A. Ladha-Sabur, S. Bakalis, P. J. Fryer, and E. Lopez-Quiroga, "Mapping energy consumption in food manufacturing," Trends Food Sci. Technol., vol. 86, pp. 270-280, Apr. 2019, doi: 10.1016/j.tifs.2019.02.034.

[66] R. Sims, A. Flammini, M. Puri, and S. Bracco, Opportunities for agrifood chains to become energy-smart, vol. 43, no. 2. 2015.

[67] D. Biagiotti, C. A. Campiotti, G. Giagnacovo, A. Latini, M. Scoccianti, and C. Viola, "Energy Efficiency in Italian Fruit and Vegetables Processing Industries in the EU Agro-Food Sector Context," Riv. DI Stud. SULLA SOSTENIBILITA', no. 2, pp. 159-174, Nov. 2014, doi: 10.3280/RISS2014-002010.

[68] FoodDrinkEurope, "Data \& trends of the European food and drink industry 2020," 2020. https://www.fooddrinkeurope.eu/publication/data-trends-of-theeuropean-food-and-drink-industry-2020/ (accessed Jan. 04, 2020).

[69] FAO, "Handbook Agribusiness: Fruit and Vegetable Processing," 2009.

[70] C. Caldeira, V. De Laurentiis, S. Corrado, F. van Holsteijn, and S. Sala, "Quantification of food waste per product group along the food supply chain in the European Union: a mass flow analysis," Resour. Conserv. Recycl., vol. 149, pp. 479-488, Oct. 2019, doi: 10.1016/j.resconrec.2019.06.011.

[71] C. Galanakis, "Food waste valorization opportunities for different food industries," in The Interaction of Food Industry and Environment, C. Galanakis, Ed. Elsevier, 2020, pp. 341-422.

[72] S. Corrado and S. Sala, "Food waste accounting along global and European food supply chains: State of the art and outlook," Waste 
Manag., vol. 79, pp. 120-131, Sep. 2018, doi: 10.1016/j.wasman.2018.07.032.

[73] European Commission, "Biodegradable waste," 2019. https://ec.europa.eu/environment/waste/compost/index.htm (accessed Feb. 04, 2020).

[74] C. Caldeira, S. Corrado, and S. Sala, "Food waste accounting Methodologies, challenges and opportunities," 2017. doi: $10.2760 / 54845$.

[75] S. K. Pramanik, F. B. Suja, S. M. Zain, and B. K. Pramanik, "The anaerobic digestion process of biogas production from food waste: Prospects and constraints," Bioresour. Technol. Reports, vol. 8, p. 100310, Dec. 2019, doi: 10.1016/j.biteb.2019.100310.

[76] F. Xu, Y. Li, X. Ge, L. Yang, and Y. Li, "Anaerobic digestion of food waste - Challenges and opportunities," Bioresour. Technol., vol. 247, pp. 1047-1058, Jan. 2018, doi: 10.1016/j.biortech.2017.09.020.

[77] IFPRI, "IMPACT Projections of Food Production, Consumption, and Net Trade to 2050, With and Without Climate Change: Extended Country-level Results for 2019 GFPR Annex Table 6," vol. V2. 2019, doi: 10.7910/DVN/WTWRMH.

[78] I. F. P. Research Institute (IFPRI), "2019 Global food policy report," 2019. doi: $10.2499 / 9780896293502$.

[79] T. Edwiges et al., "Influence of chemical composition on biochemical methane potential of fruit and vegetable waste," Waste Manag., vol. 71, pp. 618-625, Jan. 2018, doi: 10.1016/j.wasman.2017.05.030.

[80] H. Bouallagui, Y. Touhami, R. Ben Cheikh, and M. Hamdi, "Bioreactor performance in anaerobic digestion of fruit and vegetable wastes," Process Biochem., vol. 40, no. 3-4, pp. 989-995, Mar. 2005, doi: 10.1016/j.procbio.2004.03.007.

[81] B. S. Dhanya, A. Mishra, A. K. Chandel, and M. L. Verma, "Development of sustainable approaches for converting the organic waste to bioenergy," Sci. Total Environ., vol. 723, p. 138109, Jun. 2020, doi: 10.1016/j.scitotenv.2020.138109.

[82] I. Esparza, N. Jiménez-Moreno, F. Bimbela, C. Ancín-Azpilicueta, and L. M. Gandía, "Fruit and vegetable waste management: Conventional and emerging approaches," J. Environ. Manage., vol. 265, p. 110510 , Jul. 2020, doi: 10.1016/j.jenvman.2020.110510.

[83] S. K. Bhatia, H.-S. Joo, and Y.-H. Yang, "Biowaste-to-bioenergy using biological methods - A mini-review," Energy Convers. Manag., vol. 177, pp. 640-660, Dec. 2018, doi: 10.1016/j.enconman.2018.09.090.

[84] D. Elalami et al., "Effect of coupling alkaline pretreatment and sewage sludge co-digestion on methane production and fertilizer potential of digestate," Sci. Total Environ., vol. 743, p. 140670, Nov. 2020, doi: 10.1016/j.scitotenv.2020.140670.

[85] W. Wang and D.-J. Lee, "Valorization of anaerobic digestion digestate: A prospect review," Bioresour. Technol., vol. 323, p. 124626, Mar. 2021, doi: 10.1016/j.biortech.2020.124626.

[86] D. Divya, L. R. Gopinath, and P. Merlin Christy, "A review on current aspects and diverse prospects for enhancing biogas production in sustainable means," Renew. Sustain. Energy Rev., vol. 42, pp. 690-699, Feb. 2015, doi: 10.1016/j.rser.2014.10.055.

[87] K. Hagos, J. Zong, D. Li, C. Liu, and X. Lu, "Anaerobic co-digestion process for biogas production: Progress, challenges and perspectives," Renew. Sustain. Energy Rev., vol. 76, no. March 2016, pp. 1485-1496, Sep. 2017, doi: 10.1016/j.rser.2016.11.184.

[88] L. D. Nghiem, K. Koch, D. Bolzonella, and J. E. Drewes, "Full scale co-digestion of wastewater sludge and food waste: Bottlenecks and possibilities," Renew. Sustain. Energy Rev., vol. 72, pp. 354-362, May 2017, doi: 10.1016/j.rser.2017.01.062.

[89] X. Wang et al., "Study on improving anaerobic co-digestion of cow manure and corn straw by fruit and vegetable waste: Methane production and microbial community in CSTR process," Bioresour. Technol., vol. 249, pp. 290-297, Feb. 2018, doi: 10.1016/j.biortech.2017.10.038.

[90] P. Bres et al., "Performance of semi-continuous anaerobic co-digestion of poultry manure with fruit and vegetable waste and analysis of digestate quality: A bench scale study," Waste Manag., vol. 82, pp. 276-284, Dec. 2018, doi: 10.1016/j.wasman.2018.10.041.

[91] B. Koçak, A. I. Fernandez, and H. Paksoy, "Review on sensible thermal energy storage for industrial solar applications and sustainability aspects," Sol. Energy, vol. 209, pp. 135-169, Oct. 2020, doi: 10.1016/j.solener.2020.08.081.

[92] R. Smith, "Rethinking Future Industrial Energy Systems," 2019, [Online].

Available: https://www.dubrovnik2019.sdewes.org/lectures.php.

[93] J.-M. Clairand, M. Briceno-Leon, G. Escriva-Escriva, and A. M. Pantaleo, "Review of Energy Efficiency Technologies in the Food Industry: Trends, Barriers, and Opportunities," IEEE Access, vol. 8, pp. 48015-48029, 2020, doi: 10.1109/ACCESS.2020.2979077.

[94] E. S. Gaballah, T. K. Abdelkader, S. Luo, Q. Yuan, and A. El-Fatah Abomohra, "Enhancement of biogas production by integrated solar heating system: A pilot study using tubular digester," Energy, vol. 193, p. 116758, Feb. 2020, doi: 10.1016/j.energy.2019.116758.

[95] H. M. Mahmudul, M. G. Rasul, D. Akbar, and M. Mofijur, "Opportunities for solar assisted biogas plant in subtropical climate in Australia: A review," Energy Procedia, vol. 160, pp. 683-690, Feb. 2019, doi: 10.1016/j.egypro.2019.02.192.

[96] A. Gaur, C. Ménézo, and S. Giroux--Julien, "Numerical studies on thermal and electrical performance of a fully wetted absorber PVT collector with PCM as a storage medium," Renew. Energy, vol. 109, pp. 168-187, Aug. 2017, doi: 10.1016/j.renene.2017.01.062.

[97] M. Greppi and G. Fabbri, "Use of microspheres in thermally insulating hybrid solar panels," Energy Procedia, vol. 148, pp. 948-953, 2018, doi: https://doi.org/10.1016/j.egypro.2018.08.090.

[98] X. Ju, C. Xu, Y. Hu, X. Han, G. Wei, and X. Du, "A review on the development of photovoltaic/concentrated solar power (PV-CSP) hybrid systems," Sol. Energy Mater. Sol. Cells, vol. 161, pp. 305-327, Mar. 2017, doi: 10.1016/j.solmat.2016.12.004.

[99] L. Sahota and G. N. Tiwari, "Review on series connected photovoltaic thermal (PVT) systems: Analytical and experimental studies," Sol. Energy, vol. 150, pp. 96-127, 2017, doi: https://doi.org/10.1016/j.solener.2017.04.023.

[100]T. M. Sathe and A. S. Dhoble, "A review on recent advancements in photovoltaic thermal techniques," Renew. Sustain. Energy Rev., vol. 76, pp. 645-672, Sep. 2017, doi: 10.1016/j.rser.2017.03.075.

[101]A. Bianchini, A. Guzzini, M. Pellegrini, and C. Saccani, "Photovoltaic/thermal (PV/T) solar system: Experimental measurements, performance analysis and economic assessment," Renew. Energy, vol. 111, pp. 543-555, 2017, doi: https://doi.org/10.1016/j.renene.2017.04.051.

[102]M. Herrando, R. Simón, I. Guedea, and N. Fueyo, "The challenges of solar hybrid PVT systems in the food processing industry," Appl. Therm. Eng., p. 116235, 2020, doi: https://doi.org/10.1016/j.applthermaleng.2020.116235.

[103]A. Perimenis, T. Nicolay, M. Leclercq, and P. A. Gerin, "Comparison of the acidogenic and methanogenic potential of agroindustrial residues," Waste Manag., vol. 72, pp. 178-185, Feb. 2018, doi: 10.1016/j.wasman.2017.11.033.

[104]R. Dalpaz, O. Konrad, C. Cândido da Silva Cyrne, H. Panis Barzotto, C. Hasan, and M. Guerini Filho, "Using biogas for energy cogeneration: An analysis of electric and thermal energy generation from agro-industrial waste," Sustain. Energy Technol. Assessments, vol. 40, p. 100774, Aug. 2020, doi: 10.1016/j.seta.2020.100774. 